This study was supported by a grant from the Economic and Social Research Council.

1 Byme DJ, Napier A, Cuschieri A. How informed is signed consent? $B M$ 1988;296:839-40

Askew G, Pearson KW, Cryer D. Informed consent: can we educate patients? $7 R$ Coll Surg Edinb 1990;35:308-10.

3 Edwards MH. Satisfying patients' needs for surgical information. $\mathrm{Br} f$ Surg 1990;77:463-5.
4 Reynolds $M$. No news is bad news: patients' views about communication in hospital. BMF 1978;i:1673-6.

5 Cassileth BR, Zupkis RV, Sutton-Smith K, March V. Informed consent-why are its goals imperfectly realised? $N$ Engl 9 Med 1980;302:896-900

6 Villar RN, Hume AC. Informed orthopaedic consent: fact or fallacy? fournal of the Medical Defence Union 1988;4:32-3.

7 Richards J, McDonald P. Doctor-patient communication in surgery. $f R$ Soc Med 1985;78:922-4.

8 Ley P, Jain VK, Skilbeck CE. A method for decreasing patients' medication errors. Psychol Med 1976;6:599-601.
Imperial Cancer Research Fund and Medical Research Council Clinical Trial Service Unit, Nuffield Department of Clinical Medicine, University of Oxford, Radcliffe Infirmary, Oxford OX2 6HE

Zhengming Chen, research officer

Anthony Keech, research officer

Rory Collins, British heart foundation senior research fellow

Richard Peto, Imperial Cancer Research Fund professor in epidemiology and medical statistics

\section{Department of}

Endocrinology and

Chemical Pathology,

United Medical and Dental

School of Guy's and

St Thomas's Hospitals,

London

Brenda Slavin, senior lecturer

Institute of Nutrition and

Food Hygiene, Chinese

Academy of Preventive

Medicine, Beijing, People's

Republic of China

Junshi Chen, professor in

nutrition

Division of Nutritional Sciences, Cornell

University, Ithaca, New

York 14853, United States

Colin Campbell, professor in

nutritional biochemistry

Correspondence to:

Dr Zhengming Chen.

BMF 1993;306:890-4

\title{
Prolonged infection with hepatitis $B$ virus and association between low blood cholesterol concentration and liver cancer
}

\author{
Zhengming Chen, Anthony Keech, Rory Collins, Brenda Slavin, Junshi Chen, T Colin Campbell, \\ Richard Peto
}

\begin{abstract}
Objective-To determine whether prolonged infection with hepatitis $B$ virus is associated with a lower blood cholesterol concentration.

Design-Cross sectional study.

Setting-81 villages in rural China with a high prevalence of chronic infection with hepatitis $B$ virus.
\end{abstract}

Subjects -1556 apparently healthy men aged 35-64 years, randomly selected.

Main outcome measures-Hepatitis B virus carrier state; plasma concentrations of cholesterol, apolipoprotein B, and apolipoprotein A I.

Results-238 (15\%) of the men were positive for hepatitis B surface antigen, indicating that they were chronic carriers. Plasma concentration of cholesterol was $4 \cdot 2 \%(0.11 \mathrm{mmol} / \mathrm{l})$ lower among carriers (that is, positive for hepatitis $B$ surface antigen) than among non-carriers ( $95 \%$ confidence inverval $0.6 \%$ to $8.0 \%(0.01$ to $0.21 \mathrm{mmol} / \mathrm{h}), \mathrm{p}<0.05)$, and apolipoprotein $B$ concentration was $7.0 \%(0.036$ g/l) lower $(2.8 \%$ to $11.2 \%(0.014$ to $0.058 \mathrm{~g} / \mathrm{l})$, $\mathrm{p}<0.001)$. In contrast, no association was observed between plasma concentrations of cholesterol or apolipoprotein and hepatitis $B$ that had been eradicated (that is, patient positive for hepatitis B core antibody but negative for hepatitis $B$ surface antigen).

Conclusions-Chronic hepatitis B virus infection, which usually starts in early childhood in China, seems to lead not only to a greatly increased risk of death from liver disease but also to a somewhat lower cholesterol concentration in adulthood. This common cause produces an inverse association between cholesterol concentration and risk of death from liver cancer or from other chronic liver diseases.

\section{Introduction}

Several prospective epidemiological studies, set up mainly to examine the association of baseline blood concentration of cholesterol with subsequent rates of coronary heart disease, have also examined its association with subsequent rates of cancer. ${ }^{1-14} \mathrm{Most}^{1-12}$ but not all ${ }^{1314}$ have found an inverse relation between cholesterol concentration and the subsequent risk of cancer. This seems to be due, at least in part, to a lowering effect of preclinical cancer on cholesterol concentration, , $^{2-511}$ but other factors may also contribute to the inverse association. ${ }^{15} 16$

In China there are particularly high death rates from diseases of the liver. A prospective observational study in a Chinese population ${ }^{12}$ (in which the mean choles- terol concentration is unusually low by Western standards) found a significant inverse association between blood concentration of cholesterol and subsequent mortality from non-malignant liver disease or from liver cancer, although not from other types of cancer. More recently a significant excess risk of death from liver cancer and chronic liver disease has been reported among North Americans with a low blood cholesterol concentration. ${ }^{16}$ In China most deaths from liver disease are due to chronic infection with the hepatitis B virus. ${ }^{1718} \mathrm{We}$ investigated the association between low blood cholesterol concentration and liver disease ${ }^{12} 16$ by studying blood lipid concentrations among middle aged men in rural China, of whom about $15 \%$ were known to be carriers of the hepatitis B virus. ${ }^{19}$

\section{Subjects and methods} BLOOD SAMPLES

A large geographical correlation survey in rura China was conducted between September and December $1983 .{ }^{19}$ Sixty five counties throughout China were selected for the survey on the basis of wide variations in the 1973-5 death rates from seven major types of cancer (including liver cancer). ${ }^{20}$ Two rural villages in different communes within each county were randomly selected, and a random sample stratified for age, consisting of about 25 apparently healthy men and 25 women (aged 35-64 years) from each village, was studied.

A sample of fasting venous blood $(10 \mathrm{ml})$ was collected from each subject into a vacutainer. On the day of collection all blood samples were centrifuged in the local field survey centres to separate plasma from red blood cells, and $4 \mathrm{ml}$ of plasma containing $20 \mathrm{mg}$ sodium ascorbate was stored at $-20^{\circ} \mathrm{C}$. After several weeks the frozen samples were transferred to the study centre in Beijing, where they were aliquoted and stored at $-30^{\circ} \mathrm{C}$ for subsequent analysis for, among other things, hepatitis B surface antigen and hepatitis B core antibody. Aliquots from 1882 men from 46 of the 65 counties ( 81 of the 130 communes) were transported by air on dry ice to Oxford in 1989 for analysis of Helicobacter pylori antibody ${ }^{21}$ and subsequently stored at $-80^{\circ} \mathrm{C}$. Hence, before thawing out for the present analyses the samples had undergone two cycles of freezing and thawing.

\section{ASSAY OF HEPATITIS B VIRUS AND LIPID IN PLASMA}

The presence of hepatitis $B$ surface antigen was determined by a standard radioimmunoassay, ${ }^{22}$ and hepatitis B core antibody was determined by enzyme linked immunosorbent assay (ELISA) ${ }^{23}$ for 1564 of the 1882 men whose samples were stored in Oxford. For 
eight of these 1564 men insufficient sample was available for lipid analysis.

Lipid analyses for the remaining 1556 samples were carried out, blinded to presence or absence of hepatitis B surface antigen and hepatitis B core antibody, on a Cobas-Fara II centrifugal analyser (Roche Diagnostics, Welwyn) in the lipid reference laboratory of St Thomas's hospital, with a kinetic colorimetric method for cholesterol concentration and immunoturbidometry $^{24}$ for apolipoprotein B and apolipoprotein A I concentrations. Sodium ascorbate had been added in China as an antioxidant preservative. This could interfere with standard enzymatic methods for measuring plasma concentrations of cholesterol (as these involve oxidation) and so the samples were pretreated with ascorbate oxidase before the cholesterol concentration was measured. ${ }^{25}$

\section{STATISTICAL ANALYSES}

As both the prevalence of infection with hepatitis B virus and the mean cholesterol concentration vary from one village to another, the statistical analyses avoided direct comparison of cholesterol values in one village with those in another. The statistical analysis of lipids with respect to the hepatitis $B$ virus status therefore involved a permutation test, ${ }^{26}$ stratified for village and age, to test the assumption that, within any one particular village, lipid concentrations were unrelated to infection with hepatitis $B$ virus.

\section{Mathematical details}

In each village the excess lipid value for each subject is defined as the difference between the subject's lipid value and the average for his or her village $\left(\mathrm{s}^{2}\right.$ denotes the sum of the squares of these excesses, all divided by ( $\mathbf{N}-1)$, where $\mathbf{N}$ is the number of people in the village). For each village the numerator is defined as the sum of the excesses among the infected subjects and the denominator (D) as the number infected multiplied by the proportion uninfected, with the variance of the numerator being $\mathrm{s}^{2}$ multiplied by $\mathrm{D}$. Within any one village the difference in average lipid values between infected and uninfected subjects is the ratio of the numerator to the denominator (with standard deviation given by the ratio of the square root of the variance to the denominator $\left.{ }^{26}\right)$. By combining data from several villages the permutational estimate of the difference in lipid values between infected and uninfected subjects in the same village is simply the ratio of the sum of the numerators to the sum of the denominators (with standard deviation given by the ratio of the square root of the sum of the variances to the sum of the denominators)

In the results values are given with 1 SD or with $95 \%$ confidence intervals. Trend tests across age groups for

TABLE I-Prevalence of chronic infection with hepatitis $B$ virus and mean lipid concentrations by age in whole study population with ranges in 81 villages in rural China

\begin{tabular}{|c|c|c|c|c|c|c|}
\hline $\begin{array}{l}\text { Age } \\
\text { group } \\
\text { (years) }\end{array}$ & $\begin{array}{c}\text { No of } \\
\text { subjects }\end{array}$ & $\begin{array}{l}\text { No }(\%) \\
\text { with chronic } \\
\text { infection† }\end{array}$ & $\begin{array}{c}\text { No (\%) } \\
\text { with past } \\
\text { infectiont }\end{array}$ & $\begin{array}{c}\text { Mean (SD) plasma } \\
\text { cholesterol } \\
\text { (mmoll) }\end{array}$ & $\begin{array}{c}\text { Mean (SD) } \\
\text { apolipoprotein B } \\
(\mathrm{g} / 1)\end{array}$ & $\begin{array}{c}\text { Mean (SD) } \\
\text { apolipoprotein A I } \\
(\mathrm{g} / \mathrm{l})\end{array}$ \\
\hline $\begin{array}{l}35-39 \\
40-44 \\
45-49 \\
50-54 \\
55-59 \\
60-64\end{array}$ & $\begin{array}{l}321 \\
217 \\
261 \\
258 \\
268 \\
231\end{array}$ & $\begin{array}{l}55(17) \\
36(16) \\
39(15) \\
44(17) \\
29(11) \\
35(15)\end{array}$ & $\begin{array}{l}142(44) \\
115(53) \\
122(47) \\
132(51) \\
164(61) \\
119(52)\end{array}$ & $\begin{array}{l}2.48(0.81) \\
2.50(0.82) \\
2.49(0.80) \\
2.69(0.84) \\
2.68(0.83) \\
2.70(0.73)\end{array}$ & $\begin{array}{l}0.49(0.16) \\
0.51(0.16) \\
0.49(0.16) \\
0.52(0.16) \\
0.52(0.16) \\
0.52(0.14)\end{array}$ & $\begin{array}{l}1.41(0.38) \\
1.42(0.36) \\
1.34(0.33) \\
1.41(0.36) \\
1.39(0.37) \\
1.40(0.36)\end{array}$ \\
\hline All groups & 1556 & $238(15)$ & $794(51)$ & $2.59(0.82)$ & $0.51(0.16)$ & $1.39(0.36)$ \\
\hline $\begin{array}{r}\text { Regression } \\
\text { Annual c } \\
\text { Annual c }\end{array}$ & $\begin{array}{l}\text { analysis: ch } \\
\text { hange } \times 100 \\
\text { hange/SE }\end{array}$ & $\begin{array}{l}\text { Inge per year of } \\
\begin{array}{l}-1 \cdot 73 \\
-1.70\end{array}\end{array}$ & $\begin{array}{l}4 \cdot 16 \\
2 \cdot 96^{\star \star}\end{array}$ & $\begin{array}{l}9 \cdot 57 \\
4 \cdot 18^{\star \star \star}\end{array}$ & $\begin{array}{l}1 \cdot 19 \\
2 \cdot 68^{\star \star}\end{array}$ & $\begin{array}{l}-0.34 \\
-0.33\end{array}$ \\
\hline Range in 81 & villages & $0-54 \%$ & $6-100 \%$ & $1.65-3.59$ & $0.38-0.68$ & $1.02-2.05$ \\
\hline
\end{tabular}

${ }^{\star \star} \mathrm{p}<0.01 ;{ }^{\star \star \star} \mathrm{p}<00.001$.

tChronic infection means carrier of hepatitis $B$ surface antigen, while past infection means non-carrier but with antibodies to hepatitis B virus core protein lipids and for prevalences of hepatitis B were performed with standard linear regression analysis.

\section{Results}

In this rural Chinese population the prevalence of infection with hepatitis B virus was high: of 1556 samples, $238(15 \%)$ were positive for hepatitis B surface antigen - that is, they were chronic carrierswith the prevalences in particular villages ranging from $0 \%$ to $54 \%$ (table I). An additional 794 (51\%) had evidence of past infection with hepatitis $B$ virus-that is, they were positive for hepatitis B core antibody but negative for hepatitis B surface antigen-with the prevalences ranging from $6 \%$ to $100 \%$. (The overall prevalence of past infection is probably greater than this, however, as hepatitis B core antibody may not be detectable many years after infection.) The overall mean plasma concentration of cholesterol was low by Western standards at $2.59 \mathrm{mmol} / 1$ (see discussion). Apolipoprotein B and apolipoprotein A I concentrations were also low, with mean values of $0.51 \mathrm{~g} / \mathrm{l}$ and $1.39 \mathrm{~g} / \mathrm{l}$, respectively. There was about a twofold variation among the villages with respect to the mean plasma concentrations of cholesterol, apolipoprotein B, and apolipoprotein A I (table I).

Table I shows the prevalence of hepatitis B infection and the mean plasma concentrations of total cholesterol, apolipoprotein B, and apolipoprotein A I by five year age groups for the whole study population. The prevalence of hepatitis B surface antigen, reflecting chronic hepatitis B virus infection, seemed slightly higher among younger than among older people, whereas the converse tended to be true for past infection with hepatitis B virus $(p<0.01)$. Plasma concentrations of cholesterol and apolipoprotein $\mathrm{B}$ tended to increase with age, especially after 50 years (cholesterol: $p<0.001$; apolipoprotein B: $p<0.01$ ), but apolipoprotein A I concentrations did not.

Table II shows the mean plasma concentrations of total cholesterol, apolipoprotein B, and apolipoprotein A I according to presence of hepatitis $B$ virus, subdivided by the underlying prevalence of chronic hepatitis B. Figures 1 and 2 also show the relation of cholesterol and apolipoprotein B concentrations to chronic infection with hepatitis B virus both within and between villages. There was a positive geographical correlation between the prevalence of chronic hepatitis $B$ and the mean plasma concentrations of total cholesterol and apolipoprotein B. But, within particular prevalences of hepatitis B virus infection, the plasma concentrations of cholesterol, apolipoprotein B, and apolipoprotein A I were generally lower among carriers of hepatitis $B$ virus than among non-carriers. The overall differences for cholesterol and apolipoprotein B concentrations were significant after age and village membership were considered. On average, the concentration of cholesterol was $4 \cdot 2 \%(0.11 \mathrm{mmol} / \mathrm{l})$ lower $(95 \%$ confidence interval $0.6 \%$ to $8.0 \%,(0.01$ to $0.21 \mathrm{mmol} / \mathrm{l})$, $\mathrm{p}<0.05$ ) among carriers, while for apolipoprotein $\mathrm{B}$ it was $7.0 \%(0.036 \mathrm{~g} / \mathrm{l})$ lower $(2.8 \%$ to $11.2 \%(0.014$ to $0.058 \mathrm{~g} / \mathrm{l}), \mathrm{p}<0.001)$. Among people who were noncarriers-that is, negative for hepatitis B surface antigen-there were no significant associations of lipid concentrations with past infection with hepatitis B virus, as assessed by the existence of hepatitis $B$ core antibody. This was true for total cholesterol concentration (overall adjusted difference between non-carriers who were positive for hepatitis B core antibody and those who were negative for it was $0.02 \mathrm{mmol} / \mathrm{l}(-0.04$ to $0.08 \mathrm{mmol} / \mathrm{l})$, for apolipoprotein $B$ concentration $0.006 \mathrm{~g} / \mathrm{l}(-0.006$ to $0.018 \mathrm{~g} / \mathrm{l})$, and for apolipoprotein A I concentration $0.024 \mathrm{~g} / 1$ $(-0.003$ to $0.051 \mathrm{~g} / \mathrm{l}))$. 
TABLE II-Plasma concentrations of cholesterol and apolipoproteins $B$ and $A$ I according to chronic infection with hepatitis $B$ virus in four categories of prevalence of infection

\begin{tabular}{|c|c|c|c|c|c|c|c|c|c|}
\hline \multirow[b]{2}{*}{$\begin{array}{l}\text { Prevalence of } \\
\text { chronic } \\
\text { infection in } \\
\text { village (\%) }\end{array}$} & \multirow[b]{2}{*}{$\begin{array}{c}\text { No of } \\
\text { villages }\end{array}$} & \multirow[b]{2}{*}{$\begin{array}{l}\text { Presence of } \\
\text { chronic } \\
\text { infection }\end{array}$} & \multirow[b]{2}{*}{$\begin{array}{c}\text { No of } \\
\text { subjects }\end{array}$} & \multicolumn{2}{|c|}{ Cholesterol (mmol/l) } & \multicolumn{2}{|c|}{ Apolipoprotein B ( $g / 1)$} & \multicolumn{2}{|c|}{ Apolipoprotein A I (g/l) } \\
\hline & & & & $\begin{array}{l}\text { Mean of } \\
\text { individual } \\
\text { values }\end{array}$ & $\begin{array}{c}\text { Adjusted } \\
\text { difference } \\
(\mathrm{SE}) \dagger\end{array}$ & $\begin{array}{l}\text { Mean of } \\
\text { individual } \\
\text { values }\end{array}$ & $\begin{array}{c}\text { Adjusted } \\
\text { difference } \\
(\mathrm{SE}) \dagger\end{array}$ & $\begin{array}{c}\text { Mean of } \\
\text { individual } \\
\text { values }\end{array}$ & $\begin{array}{c}\text { Adjusted } \\
\text { difference } \\
(\mathrm{SE}) \dagger\end{array}$ \\
\hline$<10$ & 32 & $\begin{array}{l}\text { No } \\
\text { Yes }\end{array}$ & $\begin{array}{r}610 \\
27\end{array}$ & $\begin{array}{l}2 \cdot 44 \\
2 \cdot 34\end{array}$ & $0.12(0 \cdot 12)$ & $\begin{array}{l}0.488 \\
0.442\end{array}$ & $0.037(0.025)$ & $\begin{array}{l}1.356 \\
1.301\end{array}$ & $0.014(0.047)$ \\
\hline $10-19 \cdot 9$ & 21 & $\begin{array}{l}\text { No } \\
\text { Yes }\end{array}$ & $\begin{array}{r}337 \\
58\end{array}$ & $\begin{array}{l}2.65 \\
2.47\end{array}$ & $0.17(0.09)$ & $\begin{array}{l}0.517 \\
0.461\end{array}$ & $0.053(0.019)^{\star \star}$ & $\begin{array}{l}1.438 \\
1.374\end{array}$ & $0.066(0.045)$ \\
\hline $20-29 \cdot 9$ & 21 & $\begin{array}{l}\text { No } \\
\text { Yes }\end{array}$ & $\begin{array}{r}290 \\
90\end{array}$ & $\begin{array}{l}2 \cdot 72 \\
2 \cdot 66\end{array}$ & $0.06(0.09)$ & $\begin{array}{l}0.530 \\
0.514\end{array}$ & $0.024(0.017)$ & $\begin{array}{l}1.427 \\
1.429\end{array}$ & $0.005(0.029)$ \\
\hline $30-54 \cdot 2$ & 7 & $\begin{array}{l}\text { No } \\
\text { Yes }\end{array}$ & $\begin{array}{l}72 \\
63\end{array}$ & $\begin{array}{l}2 \cdot 90 \\
2 \cdot 78\end{array}$ & $0.08(0.11)$ & $\begin{array}{l}0.562 \\
0.534\end{array}$ & $0.018(0.024)$ & $\begin{array}{l}1.419 \\
1.408\end{array}$ & $0.012(0.043)$ \\
\hline Overall & 81 & $\begin{array}{l}\text { No } \\
\text { Yes }\end{array}$ & $\begin{array}{r}1318 \\
238\end{array}$ & $\begin{array}{l}2 \cdot 60 \\
2 \cdot 49\end{array}$ & $0.11(0.05)^{\star}$ & $\begin{array}{l}0.512 \\
0.472\end{array}$ & $0.036(0.011)^{\star \star \star}$ & $\begin{array}{l}1.398 \\
1.359\end{array}$ & $0.024(0.022)$ \\
\hline
\end{tabular}

$\star \mathrm{p}<0.05 ;{ }^{\star \star} \mathrm{p}<0.01 ; \star \star \star \star \mathrm{p}<0.001$

†Adjusted difference was estimated from adjusted mean values for infected (positive for hepatitis B surface antigen) and uninfected subjects by using permutational significance test adjusted for village membership and age.

$\ddagger$ Overall mean lipid values for infected and uninfected subjects (and their differences) have been standardised to distribution of overall population in four prevalence categories of chronic infection.
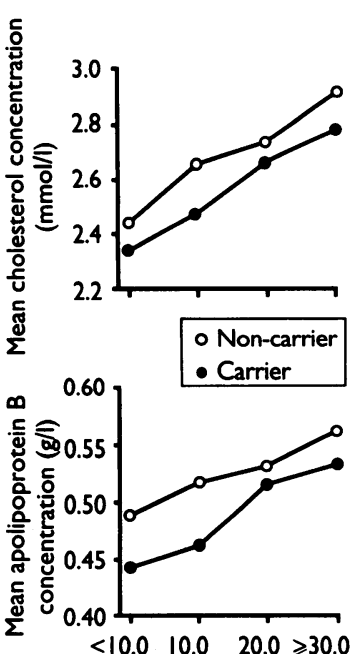

Prevalence of chronic infection with hepatitis B virus (\%)

(Top) Mean plasma concentrations of cholesterol among carriers and non-carriers of hepatitis $B$ virus in four categories of prevalence of chronic hepatitis $B$ virus; (bottom) mean plasma concentrations of apolipoprotein $B$ among carriers and noncarriers of hepatitis $B$ virus in four categories of prevalence of chronic hepatitis $B$ virus. Mean plasma concentrations of cholesterol calculated from individual values according to carrier state for hepatitis $B$ virus subdivided by underlying prevalence of chronic infection in village (see table II)

\section{Discussion}

ASSOCIATION BETWEEN CHOLESTEROL CONCENTRATION AND LIVER CANCER

An association between lower cholesterol concentrations and increased risks of cancer was first reported in 1974 for cancer of the colon. ${ }^{1}$ Such an inverse relation has since been found in several other major prospective studies for all cancers together,,$^{3-1016}$ and for three specific cancers (lung, ${ }^{349-1116}$ colon, $^{13-61016}$ and leukaemia $\left.^{41016}\right)$. In the largest study in a Western population (the multiple risk factor intervention trial) 100 deaths from liver cancer were recorded during the follow up period, and a significantly increased risk of death from liver cancer was found among people in the group with the lowest cholesterol concentrations $(<4 \cdot 1 \mathrm{mmol} / \mathrm{l}) .^{16}$ They also had a significantly increased risk of death from other chronic liver disease. In that study these increased risks of death persisted even after the deaths that occurred in the first 10 years after baseline were excluded. Most other studies in Western populations have observed too few deaths from liver cancer to examine the association with cholesterol concentration separately, although a few studies with a small number of cases of liver cancer have reported similar inverse associations between blood cholesterol concentration and risk of liver cancer. ${ }^{611}$

In our previous prospective study of another Chinese population the subsequent risk of death from liver cancer was shown to increase significantly with decreasing blood concentrations of cholesterol, with the concentrations for people who died of liver cancer being on average $8.0 \%(0.35(\mathrm{SD} 0.16) \mathrm{mmol} / \mathrm{l})$ lower than among survivors. ${ }^{12}$ An inverse association was also found between blood cholesterol concentration and death from other liver diseases, with concentrations for people who died of such diseases being on average $9.5 \%(0.39(0.20) \mathrm{mmol} / \mathrm{l})$ lower than for those who did not. These associations persisted even after exclusion of people who died in the first three years after baseline examination, indicating that they were not wholly attributable to some short term preclinical effect of liver disease reducing cholesterol concentration.

\section{CHRONIC HEPATITIS B VIRUS INFECTION, LIVER DISEASE,} AND LIPID CONCENTRATIONS

Prolonged infection of the liver with hepatitis B virus is an important cause of liver cancer and of chronic non-malignant liver disease. The prevalence of carriers of hepatitis $B$ virus is less than $1 \%$ in most Western populations, ${ }^{27}$ whereas about $10-15 \%$ of the population in China have lifelong persistent hepatitis $B$ virus infection, ${ }^{17-19}$ and this is a cause of most of that country's liver cancer and chronic liver disease.
Indeed, in a large prospective study of Chinese men in Taiwan 40 out of 41 cases of liver cancer and 17 out of 19 deaths from cirrhosis were in people positive for hepatitis B surface antigen. ${ }^{18}$ Low density lipoprotein particles account for most of the cholesterol and apolipoprotein B in the plasma, and the liver is directly involved in both the production and the resorption of low density lipoprotein particles. Hence, if chronic infection with hepatitis $\mathrm{B}$ virus lowers plasma concentrations of cholesterol in adult life this could explain the inverse association between cholesterol concentration and liver disease seen in observational studies. ${ }^{12}$ Our current study in a rural population from mainland China indicates that this may well be the case, with prolonged hepatitis B being associated with low concentrations of total cholesterol and apolipoprotein B. Similar results have also been observed in a study of 3000 Chinese adults in Taiwan (B Y Pan, personal communication) in which the mean plasma concentration of cholesterol was $4.0 \%(0.19 \mathrm{mmol} / \mathrm{l})$ lower $(p<0.001)$ among carriers of hepatitis $B$ virus than among non-carriers, after adjustment for age and body mass index. Carriers also had significantly lower concentrations of certain coagulant factors (factors II and VII and fibrinogen, which are made in the liver).$^{28}$

In principle, an alternative explanation for the inverse association between plasma cholesterol concentration and infection with hepatitis $B$ virus might be that a low plasma concentration of cholesterol (or factors that cause low concentrations) predisposes to chronic hepatitis $B$ virus infection. This does not, however, seem particularly plausible as nearly all long term carriers acquire their infection in infancy and early childhood, ${ }^{29-31}$ with about half of the infections in China being a direct consequence of maternal transmission to infants. The likelihood of becoming a chronic carrier from maternal transmission seems to depend principally on maternal titre of the surface antigen, particularly of the e antigen, which indicates particularly active infection. Indeed, over $90 \%$ of children botn to women carrying both the surface and e antigens become long term carriers ${ }^{29-31}$ irrespective of other factors. In contrast, exposure to hepatitis B virus during adulthood, when nutritional differences might be more closely correlated with adult blood lipid concentrations, rarely leads to the chronic infection. ${ }^{32}$ Furthermore, there was no association between plasma concentrations of cholesterol or apolipoprotein and past infection with hepatitis $B$ virus - that is, being positive for hepatitis B core antibody and negative for hepatitis B surface antigen.

The possibility that the association between cholesterol concentrations and hepatitis $B$ in the present 
study was due to confounding by differences in nutrition or in socioeconomic factors also seems unlikely. Although the 81 communes in the study were heterogeneous with respect to prevalence of hepatitis B virus infection and cholesterol concentrations, the people within each individual commune were compared with other people from the same village, and Chinese villages tend to be fairly homogeneous with respect to socioeconomics and diet. ${ }^{19}$ Furthermore, those who were carriers of hepatitis B were almost all asymptomatic, with no knowledge of their infection. The most plausible biological explanation would therefore seem to be that prolonged infection of the liver with hepatitis B virus, often starting in early childhood but persisting through adult life, lowers blood concentrations of cholesterol in adults.

The $4 \%$ difference in cholesterol concentrations between carriers and non-carriers of hepatitis B virus is only half the size of the difference $(8.0 \%$ for liver cancer) observed in our previous report between those who actually died of liver cancer or chronic nonmalignant liver disease and those who did not. ${ }^{12}$ But the carriers included in this study had, in general, no clinically apparent evidence of liver damage. So, although this apparent discrepancy may be due to chance (as there is overlap between the $95 \%$ confidence intervals of the two differences), it may also reflect heterogeneity in the severity of the liver damage of carriers, if the severity of damage correlates both with the reduction in cholesterol concentration and with the risk of death. This possibility is supported by a recent study in which lipoprotein(a) concentration was significantly reduced in patients with cirrhosis, the size of the reduction in lipoprotein(a) concentration being correlated with the severity of the cirrhosis. ${ }^{33}$

The low mean cholesterol concentration in China has been documented in previous studies. The measured plasma concentration of cholesterol in the present samples was only $2.59 \mathrm{mmol} / \mathrm{l}$, which is about half that seen in most Western populations. This figure is a slight underestimate, however, compared with the results of previous pooled analyses on the same samples made seven years ago which yielded a mean of 3.30 mmol/. ${ }^{19}$ The mean apolipoprotein $B$ concentration was also significantly lower in the present analysis than previously. This decrease after seven years is unlikely to be attributable to changes in laboratory methods as the measurement of apolipoprotein $\mathrm{B}$ was done in the same laboratory with the same method but may instead reflect the effects of storage and handling procedures. This should not, however, have influenced the relative difference found in lipid concentrations between carriers and non-carriers.

\section{COMPARISONS BETWEEN AND WITHIN POPULATIONS}

In this study there was a negative correlation between chronic infection with hepatitis $\mathbf{B}$ virus and blood concentrations of cholesterol (and apolipoprotein B) when people living in the same village were compared with each other, but the correlation was reversed when average values for different villages were compared with each other. An underlying cause for the substantial differences in the mean lipid concentrations between the villages is probably the differences in nutritional practices between them ${ }^{19}$ but not the differences in the prevalence of chronic hepatitis $B$, for even among non-carriers these differences in lipid concentration remain. Differences in nutritional practices and mean lipid concentrations are probably associated with differing degrees of urbanisation and industrialisation, ${ }^{19}$ but why they are correlated with the prevalence of hepatitis B infection and whether this is coincidental are not clear. Corrèlations between populations based on average measures in groups are subject to the "ecological fallacy" (whereby these correlations may not represent the correlations that would be seen among individual subjects ${ }^{34}$ ); the epidemiological strengths and weaknesses of comparisons of individual subjects within one population and of comparisons of different geographically defined populations have already been discussed in the context of this particular study. ${ }^{19}$ In general, comparisons within populations are much more reliable than comparisons between populations when assessing association of variables and diseases in individual subjects. So, in the present instance, the negative correlation observed when people living in the same village were compared with each other provides the most reliable evidence as to the real relation between chronic infection with hepatitis $B$ virus and lipid concentrations in individual subjects.

\section{SUMMARY}

Various explanations of the finding of an inverse relation between low blood concentration of cholesterol and risk of cancer have been suggested. Preclinical cancer can itself reduce cholesterol, ${ }^{2-511}$ perhaps by increased receptor activity for low density lipoprotein in cancer cells. ${ }^{35}$ We have now shown that prolonged infection with hepatitis $B$ virus is an additional factor contributing to the inverse relation between cholesterol concentration and liver cancer. Chronic hepatitis B, which usually starts in early childhood in China, leads not only to liver disease but also to a lower blood concentration of cholesterol in adulthood. This produces, as observed elsewhere, ${ }^{12}$ an inverse relation between cholesterol concentration and the risk of death from liver cancer or from other chronic liver disease. This result may also help to explain, at least in part, the inverse association between cholesterol concentration and liver disease observed in Western populations ${ }^{16}$ where chronic hepatitis $B$ virus infection, though less common, still accounts for a large proportion of liver cancer and other chronic diseases of the liver.

Zu-Ling Feng, David Forman, Peter Lumb, Joseph Cheung, and Edward Kearney helped with management and analysis of blood samples.

1 Rose G, Blackburn H, Keys A, Taylor HL, Kannel WB, Paul O, et al. Colon cancer and blood cholesterol. Lancet 1974; i:181-3.

2 Rose G, Shipley MJ. Plasma lipids and mortality: a source of error. Lancet 1980;i:523-6.

3 International Collaborative Group. Circulating cholesterol level and risk of death from cancer in men aged 40-69 years. Experience of an international collaborative group. fAMA 1982;248:2853-9.

4 Sherwin RW, Wentworth DN, Cutler JA, Hulley SB, Kuller LH, Stamler J. Serum cholesterol levels and cancer mortality in 361662 men screened for the multiple risk factor intervention trial. JAMA 1987;257:943-8.

5 Knekt P, Reunanen A, Aromaa A, Heliovaara M, Hakulinen T, Hakama M. Serum cholesterol and risk of cancer in a cohort of 39,000 men and women. IClin Epidemiol 1988.41.519-30.

6 Kagan A, McGee DL, Yano K, Rhoads GG, Nomura A. Serum cholesterol and mortality in a Japanese-American population. Am I Epidemiol 1981; and mortality

7 Williams RR, Sorlie PD, Feinleib M. Cancer incidence by levels of cholesterol. IAMA 1981;245:247-52.

8 Beaglehole R, Foulkes MA, Prior IA, Eyles EF. Cholesterol and mortality in New Zealand Maoris. BMY 1980;280:285-7.

9 Schatzkin A, Hoover RN, Taylor RR, Ziegler R, Carter CL, Larson DB, et al. Serum cholesterol and cancer in the NHANES I epidemiologic follow-up study. Lancet 1987;ii:298-301.

10 Isles CG, Hole DJ, Gillis CR, Hawthome VW, Lever AF. Plasma cholesterol, coronary heart disease, and cancer in the Renfrew and Paisley survey. BMF 1989;298:920-4.

11 Smith GD, Shipley M, Marmot MG, Rose G. Plasma cholesterol concentration and mortality-the Whitehall study. $9 A M A$ 1992;267:70-6.

12 Chen ZM, Peto R, Collins R, MacMahon S, Lu JR, Li WX. Serum cholesterol concentration and coronary heart disease in population with low cholesterol concentration and coronary heart disease

13 Salonen JT. Risk of cancer and death in relation to serum cholesterol: a longitudinal study in an eastern Finnish population with high overall cholesterol level. Am F Epidemiol 1982;116:622-30.

14 Dyer AR, Stamler J, Paul O. Serum cholesterol and risk of death from cancer and other causes in three Chicago epidemiological studies. Fournal of Chronic Disease 1981;34:249-60.

15 Jacobs D, Blackbum H, Higgins M, Reed D, Iso H, McMillan G, et al. Report of the conference on low blood cholesterol: mortality associations. Circulation 1992;86:1046-60.

16 Neaton JD, Blackburn H, Jacobs D, Kuller L, Lee DJ, Sherwin R, et al. Serum cholesterol level and mortality: findings for men screened in the multiple risk factor intervention trial. Arch Intern Med 1992;152:1490-500. 
17 Jiang YT. Epidemiological studies of viral hepatitis A and B in the People's Republic of China. In: Szmuness W, Alter HJ, Maynard JE, eds. Viral hepatitis. Philadelphia: Franklin Institute Press, 1982:121-8.

18 Beasley RP, Lin CC, Hwang LY, Chien CS. Hepatocellular carcinome and hepatitis B virus. A prospective study of 22707 men in Taiwan. Lancet 1981;ii:1129-32.

19 Chen JS, Campbell TC, Li JY, Peto R. Diet, lifestyle and morality in China: a study of the characteristics of 65 Chinese counties. Oxford: Oxford University Press, 1990.

20 Li JY, Liu BQ Li GY, Chen ZJ, Sun XD, Rong SD. Atlas of cancer mortality in the People's Republic of China. An aid for cancer control and research. Int $f$ Epidemiol 1981;10:127-33.

21 Forman D, Sitas F, Newell DG, Stacey AR, Boreham J, Peto R, et al. Geographic association of Helicobacter pylori antibody prevalence and gastric cancer mortality in rural China. Int f Cancer 1990;46:608-11.

$22 \mathrm{Ma} \mathrm{XK}$. Synthesis of $\mathrm{HBsAg}$ and its application in diagnosis of viral hepatitis B. China People's Liberation Army Medical fournal 1984;9:1-5.

23 Engvall E, Perlman P. Enzyme-linked immunoabsorbent assay (ELISA) Quantitative assay of immunoglobulin G. Immunochemistry 1971;8:871-4.

24 Mount JH, Kearney EM, Rossenen M, Slavin BM. Immunoturbidimetric assays for serum apolipoproteins A1 and B using cobas bio centrifugal analysis.

25 Lumb PJ, Slavin BM. Determination of serum cholesterol concentration in the presence of ascorbate. $f$ Clin Pathol (in press).

26 Cox DR, Hinkley DV. Distribution-free and randomisation tests. In Thoretical statistics. London: Chapman and Hall, 1974.

27 McQuillan GM, Townsend TR, Fields HA, Carroll M, Leahy M, Polk BF
Seroepidemiology of hepatitis B virus infection in the United States: 1976-1980. Am f Med 1989;87(suppl 3A):55-105.

28 Meade TW, Stirling Y, Thompson SG, Ajdukiewicz A, Barbara JAJ, Chalmers DM. Carriers of hepatitis B surface antigen: possible association between low levels of clotting factors and protection against ischaemic heart between low levels of clotting factors
disease. Thromb Res 1987;45:709-13.

29 Stevens CE, Beasley RP, Tsui J, Lee WC. Vertical transmission of hepatitis B antigen in Taiwan. N Engl f Med 1975;292:771-4.

30 Beasley RP, Trepo C, Stevens CE, Szmuness W. The e antigen and vertical transmission of hepatitis B surface antigen. Am $\mathcal{F}$ Epidemiol 1977;105:94-8.

31 Okada $\mathrm{K}$, Kamiyama I, Inomata $M$, Imai M, Miyakawa $Y$, Mayumi $M$ e Antigen and anti-e in the serum of asymptomatic carrier mothers as indicators of positive and negative transmission of hepatitis B virus to their infants. N Engl I Med 1976;294:746-9.

32 McMahon BJ, Alward WLM, Hall DB, Heyward WL, Bender TR, Francis $D$, et al. Acute hepatitis B virus infection: relation of age to the clinical expression of disease and subsequent development of the carrier state. IInfect Dis 1985;151:599-603.

33 Feely J, Barry M, Keeling PWN, Weir DG, Cooke T. Lipoprotein(a) in cirrhosis. BMF 1992;304:545-6.

34 Piantadosi S, Byar DP, Green SB. The ecological fallacy. Am 7 Epidemiol 1988;127:893-904.

35 Ueyama Y, Matsuzawa Y, Yamashita S, Funahashi T, Sakai N, Nakamura T, et al. Hypocholesterolaemic factor from gallbladder cancer cells. Lancet 1990;336:707-9.

(Accepted 25 fanuary 1993)

\section{Medical management of miscarriage: non-surgical uterine evacuation of incomplete and inevitable spontaneous abortion}

\author{
R C Henshaw, K Cooper, H El-Refaey, \\ N C Smith, A A Templeton
}

Department of Obstetrics and Gynaecology, Aberdeen Maternity

Hospital, Aberdeen AB2 9ZD

R C Henshaw, lecturer

$\mathrm{K}$ Cooper, senior house officer

H El-Refaey, clinical research

fellow

N C Smith, consultant

A A Templeton, professor of

obstetrics and gynaecology

Correspondence to:

Dr Henshaw.

BMF 1993;306:894-5

The principle of "emptying the uterus as quickly and safely as possible" remains the cornerstone of management in inevitable or incomplete spontaneous abortion. ${ }^{1}$ Surgical curettage has been used since the 1930 s, when death from haemorrhage and sepsis, often secondary to criminal abortion, was commonplace. Management has not changed despite the advent of antibiotics and legal abortion, the earlier diagnosis of miscarriage by ultrasonography, and the development of medical methods of abortion.

\section{Patients, methods, and results}

In this open study 44 eligible women (table) who were to have undergone surgical evacuation of the uterus for ultrasonically and clinically proved inevitable or incomplete miscarriage were given a single dose of sulprostone $0.5 \mathrm{mg}$ intramuscularly or misoprostol $400 \mu \mathrm{g}$ orally. The study had ethical approval, and all women gave written consent.

Sulprostone, a synthetic prostaglandin $\mathrm{E}_{2}$ analogue, was used to treat the first 20 women. After it was voluntarily withdrawn by the manufacturer we used misoprostol, a synthetic prostaglandin $\mathrm{E}_{1}$ analogue, because of its high efficacy in combination with the antigestagen mifepristone. ${ }^{2}$ As there were no significant differences between the two drugs in any of the outcomes assessed the results were combined.

Women were reviewed 12-18 hours after treatment, when pelvic examination was repeated. Surgical uterine evacuation was performed if there had been no decrease in pain, bleeding, or uterine size. Women attended for review 10-14 days later so that the success of treatment could be confirmed by clinical assessment or transvaginal ultrasonography.

Forty three women were included in the analysis (one woman was excluded as she was subsequently found to have an ectopic pregnancy). Fifteen were pregnant for the first time. At recruitment their median age was 28 (range 17-40) and the median duration of amenorrhoea was 66 (40-91) days.

During treatment 11 women required oral analgesia and two narcotic analgesia. Histologically confirmed products of conception were identified in 25 cases. Treatment failed in two women: in one products of conception lodged in the cervical canal and in the other vaginal bleeding became severe enough to warrant curettage.

Thirty eight women attended for follow up. Three women had experienced symptoms which had prompted them to contact their family doctor, while 23 had been able to return to normal daily activities immediately; in the remainder the median duration of inactivity was 3 (1-7) days. Haemoglobin concentration showed a median decrease of $2 \mathrm{~g} / \mathrm{l}$, with values ranging from a decrease of $17 \mathrm{~g} / \mathrm{l}$ to an increase of $9 \mathrm{~g} / \mathrm{l}$. No further women required either elective or emergency uterine curettage, so overall complete uterine evacuation occurred in 41 women.

\section{Comment}

This report suggests that prostaglandin analogues may be practical alternatives to surgical uterine evacuation in managing spontaneous incomplete or inevitable miscarriage; the ability of these drugs to stimulate uterine contractility is well known. ${ }^{3}$ Similar high success rates occur in medical abortion (sequential treatment with an antigestagen and a prostaglandin), which may mimic the physiological events of spontaneous miscarriage. ${ }^{3}$ Although only $88 \%$ of women were seen at follow up, none of the women who failed to attend requested treatment from her general practitioner or was readmitted to hospital (no other hospital in this area provides gynaecological services). The procedure seemed to be well tolerated: most women were rapidly able to return to normal daily activities and consultation rates with family doctors were low.

This treatment has important implications for the management of miscarriage. Women are dissatisfied

Criteria for eligibility to enter study

Sure menstrual dates and human chorionic gonadotrophin detectable in urine

No more than 13 weeks of gestation completed

History of abdominopelvic pain or vaginal bleeding, or both

Dilated uterine os and uterine size less than or equal to menstrual dates on clinical pelvic assessment

Transvaginal ultrasonographic confirmation of retained products of conception $^{\star}$

Stable haemodynamic system, with no more than moderate vaginal bleeding

Haemoglobin concentration $>104 \mathrm{~g} /$ and white cell count $<12 \times 10^{9} h$

Temperature $<37.5^{\circ} \mathrm{C}$

Temperature $<37.5^{\circ} \mathrm{C}$
No anti-prostaglandin drugs given within previous 24 hours

No anti-prostaglandin drugs given within previous 24 hours
No history of or current serious systemic medical or surgical condition

No history of or current serious systemic medical or surgical condition
No contraindication to prostaglandin treatment (mitral stenosis, glaucoma, sickle cell anaemia, hypertension, severe asthma)

No history of recurrent spontaneous abortion

*Women with an intact gestational sac without live fetus (missed abortion) or complete spontaneous abortion not requiring treatment were excluded. 